\title{
NEWS OF THE PROFESSIDN
}

\author{
Prepared by John Whitney Hall and Richard K. Beardsley*
}

The following material was received prior to February 15,1953

\section{SPECIAL REPORTS}

\section{A Survey of Oriental Studies in Great Britain ${ }^{1}$}

During the last five years Oriental studies in Great Britain have undergone very rapid expansion, especially in the universities. To gain an understanding of this development it will be necessary to review briefly the history of Oriental studies in Britain, a review which falls into three sections: (1) Before World War II; (2) During World War II; (3) Post-war developments.

\section{(1) Before World War II}

The establishment of one or two professorships in Chinese in British Universities at the end of the 19th Century, when the cultural and political importance of China came to be realized, lagged decades behind the beginning of academic work in Sanskrit and centuries behind the founding of professorships in Hebrew and Arabic. By the beginning of the present century the main British universities of Oxford, Cambridge, Manchester, Edinburgh, Glasgow, Aberdeen and St. Andrews provided some form of teaching in Oriental subjects. Among them Oxford, Cambridge and one or two others had professorships of Sanskrit and Chinese. Unfortunately although many of the holders of these professorships were very distinguished scholars, ${ }^{2}$ there was scarcely a continuous academic or scholarly tradition, for various reasons. For instance, each Professor, as the only representative of his subject in his university, not only gave all the teaching required to all grades of students of his own subject, but also was often expected to teach a range of related subjects; this is illustrated by the title "Professor of Hebrew and Oriental Languages" which only recently became extinct in one university.

When it is recalled what a prominent place Britain held at the beginning of this century in world affairs, and especially what strong political and commercial

- The Quarterly reserves the right to edit items to fit its space or subject requirements. Deadlines for receiving material are: May 15, August 15, November 15, February 15.

1 This report was prepared by E. B. Ceadel, Lecturer in Japanese, University of Cambridge, England. In it the word "Oriental" has been used to include all of Asia, except the Soviet Union, and also the Arabic-speaking areas of Africa. Emphasis has been placed, however, on Far Eastern and South-East Asian studies. The survey is restricted to British universities and does not attempt to cover such institutions as the Royal Institute of International Affairs or the British Museum.

2 Some of the more distinguished are mentioned in A. J. Arberry, British Orientalists, London, 1943. 
ties she had with India and the Far East, the academic neglect of Oriental studies at that time appears almost inexplicable. Public attention was often drawn to the situation by individuals and societies, however, and in 1907 an official govemment enquiry was made. The so-called Reay Report,' which resulted, recommended the setting-up of an Oriental School in London. This recommendation was eventually followed in 1916 by the establishment of the School of Oriental Studies (since 1938 renamed the School of Oriental and African Studies) in the University of London. The School, in spite of many difficulties of finance and accommodation, soon achieved a reputation for effective teaching and scholarship.

At the beginning of World War II in 1939, the School (usually known as the S.O.A.S.) had an academic staff of just under forty members, while the academic staff of the Faculty of Oriental Languages at Cambridge numbered merely eight, and the Oriental $F$ aculty at Oxford was of similar size. Other British universities were fortunate if they had Oriental staffs exceeding a single professor. Thus the establishment of the S.O.A.S. was a great advance, and gave encouragement to British Orientalism. Moreover, it was instrumental in turning academic institutions from the classical aspects of Oriental studies to modern problems. A very large proportion of the School's students were interested in preparing themselves for diplomatic or business careers in the Orient.

\section{(2) During World War II}

As war spread over North Africa and Asia, the very small reserve of experts in Oriental languages was soon exhausted. Emergency arrangements were necessitated for training hundreds, and in some cases thousands, of milita and civilian personnel, principally in Japanese, but also in Chinese, Arabic, Persian, Turkish and many Indian languages.

The importance of Oriental studies was thus forced upon public attention during the war, and, indirectly, the influence of the East became stronger in manifold ways. Returning veterans brought home a widened horizon, while even those who had stayed at home were steadily awakened to the political significance of Asia.

\section{(3) Post-War developments}

Such was the impact of this realization that, even while the war in Europe was at its height, the Secretary of State for Foreign Affairs after receiving representations from a number of persons specially interested in Oriental studies in Great Britain appointed in December 1944 an official Commission "to examine the facilities offered by universities and other educational institutions in Great Britain for the study of Oriental, Slavonic, East European and Afric an languages and culture, to consider what advantage is being taken of these facilities and to formulate recommendations for their improvement." The

\footnotetext{
'Report of the Committee appointed by the Lords Commissioners of His Majesty's Treasury to consider the organization of Oriental Studies in London, London, 1907.
} 
report of the Commission, under the Chairmanship of Lord Scarbrough, and hence generally known as the Scarbrough Report, was published in 1947."

One of the three principal recommendations of the Report was that an academic tradition should be built up in Oriental studies "comparable in quality and in continuity with those of the major humanities and sciences." To this aim the following recommendations were made:

(i) Strong University departments should be developed relating to these countries and in more general University departments the staff concerned with these countries should be strengthened,

(ii) The probability that the number of undergraduates is likely to remain relatively small should not hold up development,

(iii) The University departments should endeavor to maintain a balance between languages and related subjects,

(iv) A balance should also be maintained between classical and modem studies,

(v) A principal aim of development should be the closer integration of these studies with the humanities and sciences as a whole,

(vi) There should be far more provision for graduates to undertake research work both in this country and abroad and to publish their findings,

(vii) Deficiencies in libraries should be made good,

(viii) Provision should be made for University teachers to make firsthand contact with the countries about which they teach, at intervals of not more than three years,

(ix) The most pressing need is the selection and training of young scholars who may later fill junior academic posts. Funds should be made available from the Treasury to finance a total of 100 post-graduate studentships in the course of five years.

To fulfill these recommendations the Report proposed a large annual government grant to the universities which were prepared to carry out the development of their Oriental Faculties and Departments on the lines suggested. In the same year (1947) the British govemment announced its acceptance of the recommendations of the Report, and its intention to provide the financial aid required to carry them out.

To fulfill the recommendations (i) to (viii), an "earmarked" grant for Oriental (and African) studies in British universities was made to cover the years 1947 to 1952. The annual total of the grant for 1947-48 was comparatively small, but was steeply increased for each successive year, and reached approximately $£ 200,000(\$ 560,000)$ in $1951-52$. This total was divided among the various universities concemed with Oriental teaching. The largest share allocated by the University Grants Committee went naturally to the London S.O:A.S. Smaller shares were apportioned to Cambridge, Manchester, Oxford, Durham, and Edinburgh, in descending order. To fulfill recommendation (ix), the Treasury arranged post-graduate studentships to train potential teachers for university academic posts in Oriental subjects.

\footnotetext{
4Report of the Interdepartmental Commission of Enquiry on Oriental, Slavonic, East European and A/rican Studies, 1947.

"The British government was in the habit of providing "bloc" financial grants to universities, such funds being divided between the several schools and departments at the discretion of the individual universities. "Earmarked" grants were given only for certain special purposes which might otherwise be neglected.
} 
The above machinery was put into effect early in 1948. The results which can already be seen are remarkable. A survey of the developments up to the summer of 1951 has already been published, ${ }^{6}$ and further progress has been made since then. To summarize the present position briefly:

London University, Scbool of Oriental and African Studies: From a teaching staff of just under forty in 1939, the School's permanent staff had been increased during the war and immediately after it, to a 1946-47 total of seventy (consisting of 10 professorships, 5 readerships and 55 lectureships). Between then and 1951 the government "earmarked" grants enabled 119 new posts to be established (14 professorships, 18 readerships and 87 lectureships), some of which replaced existing posts that have lapsed. The present academic staff totals about 170, exclusive of temporary assistants, who are natives of Oriental countries acting as "informants" for staff research work.

The School is divided into nine Departments: India, Pakistan and Ceylon; South-east Asia and the Islands; Far East; Near and Middle East; Africa; History; Phonetics and Linguistics; Law; and Cultural Anthropology.

In spite of the wide scope of studies embraced by these Departments, the School has been extremely successful in covering most of the important languages of Asia and Africa, and most of the main aspects of the cultural disciplines related to them. The Bulletin of the School of Oriental and African Studies gives a clear indication of the range of scholarly work undertaken.

The number of students at the School has been high; in the year 1950-51 there were 238 students preparing for university degrees and diplomas and over 400 other students attending courses not leading to a degree, as well as 87 students coming from other colleges of London University for intercollegiate courses.

The School has recently opened the Percival David Foundation of Chinese Art, which houses Sir Percival David's fine collection of Chine se Ceramics, and is likely to become an important center for the study of Far Eastern Art.

Outside the School, London University has recently established two professorships of Eastern Archaeology, and teaching in some Oriental subjects is given at University College, London, and the London School of Economics; courses in Chinese Art are given at the Courtauld Institute.

Cambridge University, Faculty of Oriental Languages: The teaching staff of eight in 1939 was for the most part concerned with Near Eastern (Semitic, Islamic and related) studies. The rest of Asia was represented by one professorship of Sanskrit and one of Chinese.

Since 1947 the Faculty has developed to a teaching staff of just under 30, and the four sections of the Faculty (Ancient Near East, Islamic Studies, Indian and Iranian Studies and $\mathrm{F}$ ar Eastern Studies) are of approximately equal size.'

- The Development of Oriental Studies in British Universities 1947-51: Reports delivered at the Fi/th Conference of the Association of British Orientalists at Cambridge, 23rd to 26th July 1951, London, 1952.

${ }^{7} \mathrm{~A}$ detailed account of Far Eastern studies in the University of Cambridge was given by the present writer in the Far Eastern Quarterly, XI, No. 4 (August 1952), 517-22. 
Oxford University, Faculty of Oriental Studies: The position at Oxford in 1939 was similar to that at Cambridge, and the expansion since 1947 has been over much the same field of studies as at Cambridge, although only ten new posts have been established.

Manchester University, Faculty of Arts Department of Oriental Studies: The 1939 staff of a Professor and four Lecturers in Semitic Languages and Arabic has now been enlarged to a department of over twelve. The scope of teaching, however, remains confined to the Near East. A teaching post in Chinese has remained vacant for several years.

Durham University, Oriental Department: Most noteworthy progress has been made between 1947 and the present from a single professorship of Hebrew into a department of over ten members covering various Semitic and Islamic subjects. A lectureship in Indian Philosophy and a lectureship in Chinese philosophy have recently been established.

Edinburgh University, Faculty of Arts, Departments of Indian and Islamic Studies: The staff of four who in 1939 provided teaching in Semitic languages, Arabic and Sanskrit has been enlarged by the establishment of five other lectureships in the same and related subjects.

All the above developments have been financed by the government "earmarked" grants for Oriental (and African) studies. In addition there have been small increases in the small Oriental Departments in the Universities of Livexpool, Leeds, St. Andrews and elsewhere, financed from the general funds of the Universities concerned.

The expansion of the teaching staff in Oriental studies in the various universities took a large proportion, but not the whole, of the earmarked grants. All the universities receiving the grants have spent part of them on improving their Oriental library collections. The best of these collections are the $\mathrm{Li}$ brary of the S.O.A.S., the Oriental collections in the University Library at Cambridge and the Bodleian Library at Oxford. ${ }^{\circ}$

The publication of scholarly books on Oriental subjects has for many years been difficult in Britain, as in America, because the market for them is unlikely to be sufficiently large to encourage commercial publishers to take the risk of publishing them. University presses have made a valuable, but necessarily limited, contribution by publishing some of these books, but the need has remained pressing. Both the S.O.A.S. and the Faculty of Oriental Languages at Cambridge have devoted a part of their earmarked grants to Publication Funds. The former has subsidized the publication of a large number of Oriental theses and textbooks, and the latter has undertaken the Cambridge Oriental Series.

\footnotetext{
- Important libraries of Oriental books and books on Oriental subjects not connected with universities exist at the British Museum, the India Office, the Colonial Office, the Royal Asiatic Society, the Royal Institute of International Affairs, the Royal Geographical Society and the Royal Empire Society.
} 
The recommendation (viii) of the Scarbrough Report that teachers of Oriental subjects should "make first-hand contact with the countries about which they teach, at intervals of not more than three years" was more Utopian than realistic, although its purpose was clearly a sound one. The S.O.A.S, through determined efforts, has managed to give twelve or more members of the staff (i.e. about one in ten) study leave for a year in the Orient during each of the last three or four years. At Cambridge, travel grants have been made to several members of the staff, although it has not been possible to devote more than a small part of the "earmarked" grant to this. Oxford and other universities have also been able to make travel grants to members of their staffs.

One of the greatest difficulties involved in the expansion of teaching staffs during the last five years has been the shortage of suitably qualified candidates to fill the posts. The Scarbrough Commission had clearly foreseen this shortage, and had recommended (point $i x$, above) the granting of post-graduate studentships to train scholars to fill junior academic posts. A large number of these studentships has, in fact, been awarded, but, although they fulfil a useful function in creating a reserve of potential university teachers for the future, very few holders of the studentships have yet completed their courses and been appointed to posts. In fact most of the posts created by the period of rapid expansion in Oriental studies from 1948 to 1952 have already been filled by candidates already available or by foreign scholars. In the case of Semitic and Islamic subjects, there was already a reserve of potential teachers, since these subjects were comparatively well established in several universities. For Far Eastern subjects there was a great shortage of senior scholars, but many young men who had been given war-time training in Japanese and Chinese had continued to work on these subjects academically and could take junior appointments.

In the field of Indian and South-East Asian studies, however, the situation was very unsatisfactory, and the filling of the new vacancies has proved a problem. Both of these fields seem to be unpopular with students, and have attracted very few candidates indeed for the Treasury post-graduate studentships. The withdrawal of British administration from India in 1947 meant the retirement of most of the British members of the Indian Civil Service, and some (but surprisingly few) were fitted to take academic positions in Indian subjects. South-East Asian studies were in the worst position, and in accordance with a recommendation of the Scarbrough Report, the teaching of these subjects is concentrated in the S.O.A.S., for the time being at least, in order to prevent dispersal of the very limited resources of qualified specialists. The S.O.A.S. found considerable difficulty, even then, in filling the vacant posts in this field, and took the step of instituting trainee-lectureships with the understanding that the candidate's position on the staff would be made permanent if he made goot during his course of training. This step has proved very successful.

The above increase in teaching staffs has made it possible to provide teaching in the history, art, archaeology, religion and philosophy as well as the 
language and literature of each main Oriental civilization, and also enabled modern languages to be taught as well as classical ones. The building-up of "area studies" or "regional studies," necessarily a slow process, has also been started. Another five years of development at the rate of the last five years would probably see a great broadening of the range of Oriental studies in several British universities. Complementarily to the broadening of Oriental studies themselves, the contribution which Oriental studies can make to other branches of the humanities is being realized in most universities. As mentioned above, students from other Schools of London University attend courses at the S.O.A.S., and in other institutions courses of the Oriental Faculties and Departments similarly serve students in other branches of the humanities. Gradually, the Faculties of History, Art, Religion, Philosophy and Law in many British universities are finding that the frontiers of their subjects go beyond the confines of non-Russian Europe and North America, and are recognizing the part that Oriental studies can play in the study of the humanities and sciences as a whole.

The Scarbrough Report referred to a period of ten years as the time necessary for the proper development of Oriental studies in British universities, government grants to universities being announced in two five-year periods. The five-year period 1947-52 has just ended. The grants for the period 195257 are now known, and it has unfortunately become clear that during the coming years the development of Oriental studies, far from continuing at approximately the same rate as in the first five-year period, will be able to proceed at only a very limited pace.' The reason for this slowing down is not apparently any change of opinion about the importance of Oriental studies, but is part of an overall policy of financial economies affecting all govemment grants. It is too early to prophesy the results of this disappointing decision; but it is hoped that the progress so far made is sufficient to be consolidated without loss of ground.

The following paragraphs present a more detailed description of British facilities in the fields of Far Eastern and South-East Asian studies.

\section{Far Eastern Studies}

The present staff is as follows:

\section{A. London University, Scbool of Oriental and African Studies:}

(i) Department of the Languages and Cultures of the Far East. Chinese: W. Simon (Professor); C. Birch, J. D. Chinnery, G. B. Downer (Cantonese), A. C. Graham, D. C. Lau (Chinese Philosophy), Y. Lee, J. J. Liu, M. A. Locke, H. F. Simon, C.-H. Tai, D. E. Watkins, Katherine P. Whitaker (Lecturers).

\footnotetext{
-The "earmarked" grants to Oriental studies have been ended, being merged into the "bloc" grants, on the understanding that the universities will continue to maintain out of the "bloc" grant the various activities that were started with the "earmarked" grants.
} 
Japanese: F. J. Daniels (Reader); R. P. Dore, C. J. Dunn, B. Matsukawa, D. E. Mills, P. G. O'Neill, S. Yanada (Lecturers). Korean: I. S. Zong (Ter.porary Lecturer). Tibetan: D. L. Snellgrove (Lecturer).

(ii) Department of History. C. R. Boxer (History of the Far East) (Professor); W. G. Beasley (Japanese History), E. G. Pulleyblank (Chinese History), O. P. N. B. van der Sprenkel (Chinese History) (Lecturers).

(iii) Percival David Foundation of Chinese Art. E. D. Edwards, Professor of Chinese, Acting Head.

B. London University, Courtauld Institute of Art: S. H. Hansford (Chinese Art) (Lecturer).

C. Cambridge University, Faculty of Oriental Languages:

Chinese: Professor: vacant (formerly G. Haloun, died 1951); A. R. Davies (Classical Chinese), B. C. McKillop, S. I. Hsiung (Temporary) (Lecturers). Japanese: E. B. Ceadel, D. L. Keene (Japanese and Korean), J. R. McEwan, T. Kamei (Temporary) (Lecturers). Far Eastern History: P. van der Loon (Lecturer). Far Eastern Art and Archaeology: T. K. Cheng (Lecturer). Altaic Languages: D. Sinor (Lecturer). Tibetan: D. R. S. Bailey (Lecturer).

D. Cambridge University, Faculty of History: V. W. W. S. Purcell (Lecturer in Far Eastern History).

E. Oxford University, Faculty of Oriental Studies.

Chinese: H. H. Dubs (Professor); S. C. Wu, D. Hawkes (Lecturers). Far Eastern Art and Archaeology: W. Cohn (Research Advisor).

F. Durbam University:

Chinese Philosophy: R. W. Dawson (Lecturer).

The extent to which $F$ ar Eastem studies have been built up in British Universities since the Scarbrough Report can be judged by comparison with the position as it was in 1939, when the total number of posts in these subjects in all British universities was only twelve (of which ten concerned Chinese and two Japanese): of the twelve posts, eight were in London (seven at the S.O.A.S.), two in Oxford, one at Cambridge (the professorship of Chinese Language and History) and one at Manchester (a readership in Chinese Language and Commerce, now lapsed).

This rapid expansion has naturally brought considerable administrative problems in the universities concerned. ${ }^{10}$ In consequence the senior members of the staft have had little opportunity for the furtherance of their own research,

${ }^{10}$ These and related problems have been the main subjects of discussion at the five Conferences held so far by the Association of British Orientalists formed in 1946. The proceedings of the Conferences of 1946-7, 1949-51 have been published, as follows: Proceedings of the Sir William Jones Bicentenary Conference, London, 1947; Conference of British Orientalists, London, 1948; Proceedings in Art and Letters, XXIII, No. 2 (1949), pp. 76-82; Proceedings in Art and Letters, XXV, No. 2 (1951), pP. 3344; Proceedings in Art and Letters, XXVI, No. 2 (1952). 
and the junior members (most of them aged under 35 and new to teaching duties) have been actively engaged in the preparation of their lecture courses. It is therefore early to expect any great output of scholarly work in the form of books and articles, but the beginnings have been made, and it may be that in the next few years the harvest of what has been sown will be reaped in good measure.

Special mention must be made of the rapid improvenent of library collections in Chinese and Japanese and related subjects in the libraries of the Universities of Oxford, Cambridge and London. This was such an urgent need that the University Grants Committee in 1949 made additional non-recurrent grants for this particular purpose totalling approximately $£ 24,000(\$ 67,200)$. Professor Dubs made a noteworthy collection of over $300 \mathrm{Ts}$ 'ung-sbu in the Oxford University Chinese Faculty Library, and Professors Haloun and Simon visited China and Japan in 1949 and made large-scale purchases for the University Library, Cambridge, and the Library of the S.O.A.S. respectively. Mr. Daniels and the present writer made further extensive purchases in Japan in 1950 for the same libraries. These three libraries are believed to be the only $F$ ar Eastem libraries in Europe with large post-war accessions.

The Universities of Oxford, Cambridge and London have also joined in securing from the University Grants Committee a small subsidy to assist the revival of the joumal Asia Major. Two volumes of the New Series of Asia Major have appeared since 1949 and it is proving, and will prove, an invaluable channel for the publication of research work in the $\mathrm{F}$ ar Eastem field.

\section{South-East Asian Studies}

The present staff is as follows:

\section{London University, School of Oriental and African Studies}

(i) Department of the Languages and Cultures of Soutb-East Asia and the Islands: D. G. E. Hall (see below) (Professor); G. H. Luce (Visiting Lecturer in Burmese); C. C. Brown (Malay), R. A. D. Forrest (Tibeto-Burman Languages), P. J. Honey (Vietnamese), C. Hooykaas (Old Javanese), H. G. A. Hughes (Polynesian Languages), M. Blanche Lewis (Malay), G. B. Milner (Oceanic Languages), Hla Pe (Burmese), H. F. Searle (Burmese), E. H. S. Simmonds (Thai), H. L. Shorto (Môn), J. M. Stead (Cambodian) (Lecturers).

(ii) Department of History: D. G. E. Hall (Professor of the History of SouthEast Asia), C. D. Cowan, H. R. Tinker (Lecturers in the History of SouthEast Asia).

(iii) Department of Cultural Antbropology: J. P. Mills (Reader in Language and Culture with special reference to South-East Asia).

\section{INSTITUTIONS AND ORGANIZATIONS}

Center for International Studies (Harvard and Massachusetts Institute of Technology). A "Middletown" study of a community in Java began with the 
arrival in Java, in October 1952, of the first members of the Gadjah MadaHarvard research project. The director, Rufus Hendon, of the Institute of $F$ ar Eastem Languages, Yale University, heads a group of seven advanced graduate students froin Harvard, under the sponsorship of the Center for International Studies, to make a multidisciplinary study for a year or more of Wonosobo or a similar community. Social structure, religion, women's life, child raising, communications, the place of Chinese, and life in neighbouring desa, will be studied from the viewpoints of social anthropology, sociology, social psychology, or history. The ensuing report will be a jointly composed community study, the first of its kind in Java. A grant from the Ford Foundation supports the project.

Cornell University. A Conference on Far Eastem Studies for Up-state New York and Southern Ontario was held at Comell University on October 31 and November 1, 1952. Ninety-five persons attended from nineteen colleges and universities in the area. The program was introduced by a lecture delivered by Dr. Ali Sastroamidjojo, Indonesian Ambassador to the United States. Three discussion sessions dealt with: "Aims, Organization and Content of General Courses on the Far East" (led by Shannon McCune, geographer and Korean specialist of Colgate University), "Professional Opportunities for Students of the Far East" (led by John M. Echols, linguist and Indonesian specialist of Cornell University), and "Far Eastem Research" (led by George B. Cressey, geographer and China specialist of Syracuse University). Members of the conference decided to meet again in the fall of 1953 at Syracuse University.

Kokusai Bunka Sbinkokai (Tokyo, Japan). The KBS, established in 1934 and reorganized after the war into a purely independent organization, aims at activities to facilitate and further the understanding of Japanese culture abroad. It stands ready to serve interested foreign institutions and individuals as a clearing house for information and materials needed for the study of Japanese culture.

The KBS maintains two libraries devoted to Japanese and Vestem books on the subject; offers for use at reasonable prices various cultural materials including lantern-slides of Japanese arts, photographic prints and movie films on Japanese culture, gramaphone records of representative Japanese music, etc.; gives regularly Japanese cultural lectures for interested foreigners, and engages in publication of books on Japanese culture.

Among present KBS projects is its preparation of an Encyclopaedia Nipponica. Publication of the annual KBS bibliographical register on important books and articles published in Japan is at a standstill owing to lack of funds. Scholars most closely associated with the society are Professor Mikinosuke Ishida, Yukio Yashiro, Keizo Horiuchi, Kotaro Tanaka and Ino Dan.

University of Manila (Manila, Philippines), has begun the publication of a quarterly, The University of Manila Journal of East Asiatic Studies (Vol. I, No. 1, Oct., 1951). 
University of Michigan. The Center for Japanese Studies announces the preparation of an educational film, "Rice Culture of Japan." Filming in color was done by Mr. Ronald Anderson. Final production, including the addition of sound track, was accomplished in cooperation with the University's Audio Visual Center.

University of Neu Hampshire (Durham, New Hampshire) offers a year course in History of the Far East taught by Dr. G. R. Johnson. A course in World Civilization, required of all students in the Liberal Arts Curriculum, touches upon the Far East and Southeast Asia.

Sophia University (Tokyo, Japan). While the primary aim of Sophia University is to teach Western civilization to Japanese students, the editorial of fice of Monumenta Nipponica has become a center of Far Eastem Studies. The joumal, begun in 1938 by the late Dr. J. B. Kraus, S. J., was obliged to cease publication in 1943 but resumed in 1951. In addition to the joumal, the University has published monographs on $F$ ar Eastern subjects at irregular intervals. Research projects now under way include work on the history of early Christian missions in Japan (Professor John Laures, S. J., and Professor Hubert Cieslik, S. J.), a comparative study of Zen and Christian mystiçism (Professor Heinrich Dumoulin, S. J.), and reconstruction of the primitive text of the l-ching (Professor Wilhelm Schiffer, S. J.). The work on Christian missions is based on a rich collection of documents known as the "Kirishitan Bunko." Professor Laurence Battistini, in Japan on a special grant from Brown University, is planning research in the modern social history of Japan, and Professor Robert A. Wilson, of the University of California, in Japan on a Fulbright grant, is working on late Tokugawa and early Meiji history.

University of Wisconsin. An undergraduate major and a graduate major in East Asian Studies are being offered at the University of Wisconsin beginning the academic year 1952-53. Professor Martin Bronfenbrenner, Department of Economics, recently back from Thailand, is offering in the fall semester a new course in "Economic Problems of the Far East." The Department of History has announced the granting of doctorates to Dun-jen $\mathrm{Li}$, with the thesis "The Economic Development of British Malaya, 1895-1938, a Study of British Imperialism in the Far East," and to Sidney Devere Brown, whose thesis is entitled "Kido Takayoshi and the Meiji Restoration, a Political Biography 1833-1877."

\section{FOUNDATIONS}

Carnegie Corporation of New York has granted $\$ 200,000$ for a program of study of islands of the Pacific by the University of Hawaii, Bernice P. Bishop Museum, and Yale University. To increase knowledge of the processes of culture change, the program will a) seek to clarify the steps by which man first brought culture into the Pacific area and adapted it to local conditions; 
and b) examine contemporary change as it is occurring today among diverse island peoples with divergent culture patterns.

\section{Rocke/eller Foundation}

Up to October 1952 the following institutions had received grants for activities in connection with the Far East and Southeast Asia.

Aicbi University, Toyohashi, Japan, $\$ 5,200$ for purchase of Westem publications on China, travel to the United States for acquaintance with the work of American centers of Chinese Studies, and additional development of an international studies program.

Institute of Public Health, Tokyo, Japan, \$25,000 for the purchase of teaching facilities, materials, and equipment; and $\$ 3000$ for the continuation of health and demographic studies in Japan.

International House of Japan, Tokyo, Japan, $\$ 176,120$ as part a fund for the establishment and support of an international center in Tokyo designed to facilitate intellectual and cultural contacts between the Japanese and people of other nationalities. Land has been purchased in Azabu, Tokyo for a permanent building to be erected during the coming calendar year. The building will provide linited residence accomodations for Japanese, American and other foreign scholars, students and leaders, a lecture hall and discussion rooms, and a limited selected library of up-to-date books and periodicals in various fields. A Japanese director and American co-director will supervise the program of the house.

Library of Congress, Washington, D. C., \$10,000 for books and periodicals on the Soviet Union to go to the National Diet Library, Tokyo, and to the Library at Hokkaido University.

National Diet Library, Tokyo, Japan, $\$ 41,000$ for a microfilm laboratory for storage of major newspaper and periodical files, protection of rare materials and other aids to research by scholars in Japan and abroad.

Researcb Institute of Population Problems, Tokyo, Japan, \$2,650 for completion, tabulation, translation and publication in English of a factual survey of fertility and family limitation practices in Japan.

Stanford University, $\$ 2,500$ for preparation for publication of an English version of the section on Japanese thought in a two-volume work by Hajime Nakamura.

\section{PERSONNEL}

Virginia Thompson Adloff is giving a series of six lectures on "Peoples of Southeast Asia: Minorities and Other Little-Known Groups" at the University of California, Berkeley, during March and April 1953, by arrangement with the Institute of East Asiatic Studies. 
Hans Bielenstein a former student of Professor Bernhard Karlgren who has been engaged in Chinese historical research in the East Asiatic Library, University of California, Berkeley, has been apnointed Professor of Oriental Languages at Canberra University College, Canberra, Australia.

Martin Bronfen/renner, Associate Professor of Economics at the University of Wisconsin, spent the second semester of 1951-52 on leave of absence in the $\mathrm{Far}$ East. He served during the period as economic consultant to ECAFE in Bangkok, Thailand, working on problems of inflation and national economy. During summer session, he conducted a graduate-faculty seminar in economic theory as visiting professor at Doshisha University, Kyoto, Japan.

Delmer M. Brown, Associate Professor of History at the University of California, Berkeley, has taken leave of absence to work with the Committee for Free Asia in Hongkong from February 1953 to August 1954.

Jobn F. Keinitz, Professor of Art History, of the University of Wisconsin, was awarded a Ford Foundation Fellowship tor the study of Chinese for the academic year 1951-52. His first semester was spent in resident study with Dr. Wang Yi-t'ung, and the second semester at the University of California working under Professors Boodberg and Schafer.

Edwin M. Loeb, Lecturer in Geography at the University of Califomia, Berkeley, has recently retumed from research in Europe and Africa, and is giving a course on the Anthropo-Geography of Southeast Asia during the spring semester, 1953.

David G. Mandelbaum, Professor of Anthropology at the University of Califomia, Berkeley, has received a Fulbright research grant to go to England to study anthropological bases for govemmental development programs in Asia. $\mathrm{He}$ is carrying on research at Oxford and Cambridge Universities from February to September 1953.

L. George Paik, president of Chosun Christian University at Pusan, Korea, recently served as Consultant for the Korean Studies Guide project of the Institute of East Asiatic Studies, University of California, Berkeley, during a two-months' visit to the United States. Dr. Paik was formerly Minister of Education for the Republic of Korea, and represented his government in the UNESCO conference in Paris in November and December, 1952.

Doo Soo Sub, Ph.D. (Columbia Teachers College) '52, former professor and dean at Seoul National University, has been appointed Visiting Professor for the present academic year in the Department of $F$ ar Eastern Languages, Harvard Lniversity. He is offering one intensive course in the Korean language and a general course on Korean civilization. 
Michael Sullivan, who received his Ph.D. degree at Harvard with a thesis on "Early Chinese Landscape Painting" (June 1952), has been appointed a Research Scholar in Fine Arts, and is continuing this study on a two year research fellowship from the Bollingen Foundation (for the years 1953 and 1954). 